Вісник Національного університету “Львівська політехніка”. Серія "Проблеми економіки та управління"

№ 2(8), 2020

UDC 332.025

JEL Classification Code Q10, L51

O. M. Hvozd, M. O. Goryn

Ivan Franko National University of Lviv

\title{
STATE REGULATION AND SUPPORT OF ORGANIC FARMING IN CANADA AND UKRAINE: AN OVERVIEW OF KEY INDICATORS AND COMPARATIVE ANALYSIS OF BOTH COUNTRIES
}

\author{
http://doi.org/10.23939/semi2020.02.125
}

(C) Hvozd O. M., Goryn M. O., 2020

The goal of organic agricultural production is to provide humanity with high-quality food without genetically modified organisms and to support the sustainability of society. It is noted that the many benefits of organic agriculture make us think about the prospects for the development of global agriculture as one of the key factors influencing the future of the next generations. $n$ this article we outline the main stages of evolution in the organic farming sphere and emphasize the characteristics that are relevant to each stage; define the term "organic farming" specified for Canadian and Ukrainian legislative systems. This paper also highlights the main prerequisites for the need for state support for organic production in the world on the example of two big organic producers - Canada and Ukraine. Based on the main indicators of the current state and level of development in both countries, the need for government regulation, support, and stimulation are considered.

The main approaches to the stimulation and development of organic production in Canada are considered in order to determine priorities for Ukraine.

It is established that subsidies for organic agriculture in Canada at one time gave an extremely important impetus to the development of this area of agricultural production, which ultimately led to significant progress in environmental protection, climate change mitigation, health, development of rural areas, and consumer protection. Also, it gave a significant boost for the national farmers, so they could grow in the area and improve their farming activity using innovative technologies.

The domestic experience of financial and organizational and legal support of the organic sphere at the state and regional levels for the formation of areas for improvement is analyzed. The necessity of not only direct financial state support, but also active educational, research, and organizational support together with representatives of the active community and business has been proved.

It was recovered that the main problems of the development of organic farming in Ukraine and obstacles to the formation of green policy in the field of agriculture include the following: lack of state control and statistical reporting of production, circulation, and sale of organic production; lack of developed infrastructure in the organic sector of the agricultural sector; imperfection of the system of certification and labeling of organic products, inconsistency of these processes with European standards; lack of state support programs for organic producers and an insufficient number of local support programs.

The necessity of a systematic approach to the stimulation and development of the domestic organic sphere to ensure the sustainability of the agricultural sector of Ukraine is substantiated. It is established that the policy of organic support in our country is not yet 


\section{O. M. Hvozd, M. O. Goryn}

characterized by a high level of system and consistency, but important initial steps have been taken in the areas of organizational, legal, and financial support of organic production.

Key words: organic farming; organic food; state regulation of organics; state support of organic farming; regional support of organic farming; subsidies for organic agriculture.

\section{Formulation of the problem}

Given the desire of modern society to maximize the conservation of natural resources, green production and minimize interference in the biosphere, the concept of sustainable development is becoming widespread, which aims to reduce the gap between the three major systems: environment, society and economy. The comprehension of the need for organic production as a mechanism of transition to the model of sustainable development of the agro-industrial complex, to replace the traditional intensive type of agricultural production, also comes to the fore. This, as a result, will allow the population to receive high-quality and safe food, promote the development of rural areas, bring organic products to a competitive level in both domestic and world markets.

State regulation and support of the organic farming must be one of the main priorities in every country to achieve all the long-term benefits from the green agricultural production. But, unfortunately, this sector of the economy does not have as much stimulation as it needs to have.

\section{Analysis of the recent research and publications}

One of the most important contributions to the development of the organic farming was made by Mokishi Okada, who is considered to be the founder of this new ideology of agriculture. He wrote that agriculture should fulfill the following missions: to offer food products that not only support human life but also improve health and environment.

Canadian researchers and scholars are a bit forward from Ukrainian ones in their investigations of organic farming. Among the nowadays scientist it is necessary to mention Trevor Pitcher, Daniel Heath, Dennis Higgs, Nicholas Bernier, Brian Dixon and others who pay attention in their studies towards effective methods of organic farming and abilities of state support for organic enterpreneurs. Also, they study current trends in organics sphere and try to implement new techniques of green farming in their country which are used in foreign cultures.

Problems of development and functioning of organic agriculture in Ukrainian science are the subject of research of such scholars as I. Ovsynsky and A. Podolynsky, V. Artysh, O. Dudar, T. Zaychuk, V. Kysil, L. Sokol, T. Stefanovska, V. Shlapak, I. Shuvar and others. They paid great attention to legislation, in particular, state support for organic farming in Ukraine. They considered the state special complex programs of organic farming as the main element of providing state support for such an economy.

However, there is a need for detailed systematic research in the field of promising trends in organic farming, which highlights the main problems of such farms in the agri-food system of Ukraine and emphasizes clearly defined trends in domestic organic farming and agriculture in general.

\section{Setting objectives}

The objectives of this scientific paper are to study main trends in the Canadian and Ukrainian organic sphere in order to analyse and compare them to define main trends on the organic market. Also, it is important to research the state support and stimulation that is provided in both countries and to propose some improvements that could be provided.

\section{Presenting main material}

Organic agricultural production is a multifunctional agroeconomic model of production that does not use genetically modified organisms and synthetic chemical fertilizers; aims to provide humanity with quality food; cares for the environment and which is conducted in compliance with legislation in the field of organic production, circulation and labeling of organic products. In the same time while Ukraine has some problems with the ability of the population to buy high-quality food, the demand for healthy and clean products in Canada has experienced a dramatical increase, similarly to all well-developed countries 
State regulation and support of organic farming in Canada and Ukraine: an overview of key indicators...

in the world. The preference in food is now given not to the caloric content of the diet, but to its beneficial effects on the body, the human immune system, protection from different diseases. To maintain the required level of supply the state and regional governments support organic farmers providing subsidies.

Before studying the main trends of organic it is necessary to clarify what does the term "organic farming" mean. There are lots of definitions of organic farming but the most common one is the definition of The International Federation of Organic Agriculture Movements (IFOAM) which states: "Organic Agriculture is a production system that sustains the health of soils, ecosystems and people. It relies on ecological processes, biodiversity and cycles adapted to local conditions, rather than the use of inputs with adverse effects. Organic Agriculture combines tradition, innovation and science to benefit the shared environment and promote fair relationships and a good quality of life for all involved" [1].

V. Artysh singles out an interesting approach to the division of the evolution of the development of organic agricultural production in his works [2].

Table 1

Main stages of evolution of the organic farming

\begin{tabular}{|l|l|}
\hline \multicolumn{1}{|c|}{ Stage } & \multicolumn{1}{|c|}{ Main characteristics } \\
\hline $\begin{array}{l}\text { 60-70s of the XX century origin of the idea of organic } \\
\text { production }\end{array}$ & $\begin{array}{l}\text { 1. The emergence of the idea of "green movement", which promotes care } \\
\text { for the environment and a healthy lifestyle. } \\
\text { 2. Formation of initiative groups that switched to the production and } \\
\text { consumption of organic products grown without the use of chemical } \\
\text { fertilizers. Dominated by subsistence farming, are created specialized } \\
\text { mini-shops. There is no active market penetration }\end{array}$ \\
\hline $\begin{array}{l}\text { 80-90s of the XX century } \\
\text { organic products }\end{array}$ & $\begin{array}{l}\text { 1. The growing popularity of environmental ideas among the population. } \\
\text { 2. The emergence of active demand for organic products }- \text { the } \\
\text { spontaneous formation of a specialized market, increasing the number of } \\
\text { organic producers, opening stores for organic products }\end{array}$ \\
\hline $\begin{array}{l}\text { 90s of the XX century - the beginning } \\
\text { of the XXI century } \\
\text { Development and standardization of the } \\
\text { market of ecological products }\end{array}$ & $\begin{array}{l}\text { 1. Increasing interest in the promising market of organic products by } \\
\text { governments and big business. } \\
\text { 2. Establishment of a system of state regulation of the market of organic } \\
\text { products. Creation of national standards and certification systems. } \\
\text { 3. Dynamic development of the market of organic products and annual } \\
\text { growth rates }\end{array}$ \\
\hline
\end{tabular}

Source: [2, p. 113-116].

Ukrainian law provides one more definition of organic production as "a certified activity related to the production of agricultural products, including all stages of the technological process, namely primary production (including harvesting), preparation, processing, mixing and related procedures, filling, packaging, processing, restoration and other changes in the state of production), which is carried out in compliance with the requirements of the legislation in the field of organic production, circulation and labeling of organic products". According to this law, organic products are "agricultural products, including food and feed, obtained as a result of organic production" [3].

The Canadian government was one of the first to pay attention to the environmental aspect of the product and took it as the basis of production. Environmental legislation has been actively implemented in Canada since the 1970s. The concept of sustainable development has been the basis of the official policy of the Canadian state since the early 1990s when the country adopted the "Green Plan of Canada". The Ministry of Agriculture and Food of Canada developed its sustainable development strategy in 1997, and earlier, in 1990, the Agricultural Committee on Sustainable Development, bringing together federal and provincial authorities, adopted an agroecosystem approach to agricultural development based on taking into account the natural links between wildlife and agricultural processes [4]. 


\section{O. M. Hvozd, M. O. Goryn}

In fact, it was a question of creating such a direction in agricultural production, which would ensure the production of environmentally friendly products - what is now called "organic food". It must be said that many Canadian farmers have responded to this government initiative, and now in Canada, you can find several farms that are engaged in "organic agriculture", use natural processes in their production, giving up the use of any chemicals, and thus way environmentally friendly products.

Such environmentally friendly products are 1.5-3 times more expensive than conventional ones. The requirements for their manufacturers are extremely strict. Land on which it is planned to grow ecologically clean products must undergo a cleaning procedure within three years (only after that it can be issued an ecological certificate). During production, it is forbidden to use chemical and mineral fertilizers, and also genetically modified cultures. The use of manual labor is positively assessed. For a product to be called an organic and ecological label, it must contain $95 \%$ organic matter. And the remaining $5 \%$ must be approved for use by the "List of Permitted Substances". When it comes to organic agriculture, it is not a question of novelty or modernization, but of a return to traditions, origins, but at a new qualitative level [5].

In 2018, Canada had 1.3 million hectares of certified organic land, which was $2 \%$ of all agricultural land and was managed by 5791 organic producers. The volume of the domestic market of organic products was more than 3 billion euros [6].

The Government of Canada actively supports the organic movement of the country in both financial and political aspects. Since October 2015, about \$C20 million have been invested to support the organic sector for:

- improvement of innovative organic technologies;

- help organic farmers and processors to take full advantage of market opportunities;

- financing jobs for young people in the organic sector;

- conducting organic research activities [7].

Organic production in Ukraine began to develop only in the late 1990s. Over time, the country is increasingly asserting itself in the international market of organic products, occupying one of the leading positions in the world in terms of agricultural land involved in their cultivation, export of raw materials and processed products.

Today in Ukraine the situation with organic farming is quite ambiguous. There are no laws in this area, the state does not support organic producers in any way, but the industry is gradually developing. As of the beginning of 2003, 31 certified organic farms were registered in Ukraine, and in 2018 there were 501 producers that received the status of "organic". The area of agricultural land under organic production was 309.1 thousand hectares, which is $0.7 \%$ of the total volume of agricultural land according to the FiBL servey [6]. At present, Ukraine ranks first in the Eastern European region in terms of certified area of organic arable land, specializing mainly in the production of cereals, legumes and oilseeds. Most Ukrainian organic farms are located in Odesa, Kherson, Poltava, Vinnytsia, Zakarpattia, Lviv, Ternopil and Khmelnytsky regions.

The adoption of the regulatory framework of organic food is relevant for our country because it will create the conditions for equal functioning of economic entities in this area and protect consumers from producers who only pretend to be organic. After all, according to the Zaychuk's study, about half of large domestic manufacturers without certification and environmental expertise put on the packaging of their products are marked "bio" or "environmentally friendly product" and automatically increase prices by 20 $30 \%$ [8]. Therefore, under conditions when any manufacturer can declare its product "environmentally friendly" without any legal responsibility, the level of trust in various eco-labeling systems goes to zero.

In Canada, food safety regulations, directives and regulations are developed by the Canadian Federal Health Service (NCS), and standards are monitored and supervised by the Canadian Food Quality Control Board (CFIA). In Ukraine, the food safety assurance system includes four ministries and seven committees and services: the Ministry of Health (MOH), the Ministry of Agrarian Policy and Food (MAPP), the Ministry of Economic Development and Trade (MEDT), and the Ministry of Ecology and Natural Resources (MENR); State Sanitary and Epidemiological Service (SSS), State Plant Quarantine Service (SSRC), State Committee of Veterinary Medicine (SCVM), State Committee of Ukraine for Technical 
State regulation and support of organic farming in Canada and Ukraine: an overview of key indicators...

Regulation and Consumer Policy (Derzhspozhyvstandart of Ukraine), State Customs Service (SCSU) Inspectorate (DEI), the National Accreditation Agency (NAAU), as well as 29 centers of standardization, metrology and certification and 4 scientific institutions of Derzhspozhyvstandart (State Committee of Ukraine for Technical Regulation and Consumer Policy), which monitor food quality, norms and standards production. The comparative analysis of main indicators of regulation systems of organics in both countries is presented in the Table 2 .

Table 2

\section{Comparative analysis of state regulation in Canada and Ukraine [6]}

\begin{tabular}{|l|l|l|}
\hline \multicolumn{1}{|c|}{ Main indicators } & \multicolumn{1}{|c|}{$\begin{array}{c}\text { Regulation of organic market } \\
\text { in Canada }\end{array}$} & \multicolumn{1}{c|}{$\begin{array}{c}\text { Regulation of organic market } \\
\text { in Ukraine }\end{array}$} \\
\hline $\begin{array}{l}\text { 1. The presense of a clear } \\
\text { regulatory legislation }\end{array}$ & $\begin{array}{l}\text { All necessary bylaws are fully } \\
\text { developed and updated to ensure the } \\
\text { effective operation of the organic } \\
\text { regulatory system. Main of them are: } \\
\text { - food and drugs act; } \\
\text { - consumer packaging and labeling } \\
\text { act; } \\
\text { - competition act }\end{array}$ & $\begin{array}{l}\text { The necessary bylaws to regulate } \\
\text { organics have been partially } \\
\text { implemented. The regulatory } \\
\text { framework is being improved and } \\
\text { developed. The main law in this area } \\
\text { is the Law of Ukraine "On basic } \\
\text { principles and requirements for } \\
\text { organic production, circulation and } \\
\text { labeling of organic products" }\end{array}$ \\
\hline $\begin{array}{l}\text { 2. Availability of universal } \\
\text { principles and structure of } \\
\text { certification of organic products }\end{array}$ & $\begin{array}{l}\text { The list of concrete national and } \\
\text { foreign organic product certification } \\
\text { bodies is defined. Existing regulatory } \\
\text { acts make it possible to clearly } \\
\text { understand the procedure for } \\
\text { certification }\end{array}$ & $\begin{array}{l}\text { Some of the sertification standarts } \\
\text { need improvement, lack of state } \\
\text { accreditation certification body }\end{array}$ \\
\hline $\begin{array}{l}\text { 3. State and regional support } \\
\text { complex }\end{array}$ & $\begin{array}{l}\text { Availability of huge range of different } \\
\text { state and regional support programs } \\
\text { for organic farmers } \\
\text { implemented regulatory measures }\end{array}$ & $\begin{array}{l}\text { Availability of few regional support } \\
\text { programs for organic farmers. Current } \\
\text { situation could be described as the } \\
\text { beginning of the introduction at the } \\
\text { legislative level of state support for } \\
\text { organic producers }\end{array}$ \\
\hline
\end{tabular}

Practically, in Ukraine there are 4-5 times more institutions than abroad that regulate quality, safety, food production standards. Therefore, it is likely that in our country the level of food quality should be high. However, according to statistics, every year the Ministry of Health of Ukraine registers almost 1.5 thousand cases of food poisoning, $70 \%$ of which are caused by the consumption of products of inadequate quality [9]. As there is currently no tendency to reduce the risks associated with food poisoning and other negative consequences of intensification of agriculture, violations in the production, transportation and sale of food, the above Ukrainian institutions are inefficient and do not perform their functions.

According to scientists S. Belinska, N. Orlova, Y. Motuzka, the main shortcomings of the domestic system of state control of food safety are due to a number of factors, including: duplication of functions of control bodies, lack of clear organizational structure at the national level, slow implementation of riskoriented system security management - HACCP systems [10].

IFC expert Criscolo, at the expense of reforming the system of supervision over food safety and quality, aptly stated: "First of all, it is necessary to establish an effective exchange of information between agencies involved in the control process, or create a single structure - the agency responsible for food. This is not a need or an invention of Ukraine - it is a modern international practice. In addition, it should be understood that the obligation to society for food safety should be borne by the producer, and the state - to retain control functions" [11]. 


\section{O. M. Hvozd, M. O. Goryn}

In our opinion, the biggest difference between Canadian and Ukrainian organic regulation systems is the fact that Ukraine does not have completely formed its support and statistics mechanisms in organic farming and as a cause, our country has not opened its full potential in this sphere. The main problems of the development of organic farming in Ukraine and obstacles to the formation of green policy in the field of agriculture include the following:

- lack of state control and statistical reporting of production, circulation, and sale of organic production;

- lack of developed infrastructure in the organic sector of the agricultural sector;

- imperfection of the system of certification and labeling of organic products, inconsistency of these processes with european standards;

- lack of state support programs for organic producers and an insufficient number of local support programs.

\section{Conclusions}

According to the results of the study, the state of food security and the situation with organic food in Ukraine is unsatisfactory compared to Canada. With significant agricultural potential, the volume of domestic environmental products is insufficient to meet the needs of the population. To our mind, in order to improve the effectiveness of organic farming in Ukraine it is necessary:

- to ensure the mechanism of financial support for organic farmers by paying subsidies to them in dependence to the area of land that they own;

- to establish on a national level a statistical regulation for all main indicators of organic production and organic market indicators that would provide a deeper understanding of the current position of organics and improvement vectors;

- to form a state accreditation certification body which would guarantee the process of certification for national organic farmers.

\section{Prospects for further research}

The state regulation of organic farming requires further research since this issue is developing all over the world from year to year and some innovative technologies are used as well as new production and certification methods are invented.

Furthermore, some of the nowadays existing thing that should be studied more, we guess, are information accessibility on organic production for consumers, marketing support of organic products on the market, and setting up a system of state order for organic products.

1. Choose Canada organic. Available at: https://choosecanadaorganic.ca/organic101/

2. Артиш В. І. (2010) Розвиток світового ринку органічної продукції. Економіка АПК, № 3, С. 113-116.

3. Про базові принципи та вимоги до органічного виробництва, обігу та маркування органічної продукції: Закон України від 03.07.2019 № 2496-VII. Available at: https://zakon.rada.gov.ua/laws/show/2496-19.

4. Federal-Provincial Agricultural Committee on Environmental Sustainability (1990). Growing Together: Report to Ministry of Agriculture. Ottawa.

5. Зайчук Т. О. (2009). Виробництво екологічно чистих продуктів харчування як стратегічний напрямок розвитку України. Економіка і регіон. Серія: Економіка та управління національним господарством, ПолтНУ, № 1 (20), C. 101 .

6. https://www.fibl.org/fileadmin/documents/shop/5011-organic-world-2020.pdf

7. The official website of Canadian Government. Available at: https://www.canada.ca/en/agriculture-agri food/news/2018/01/supporting_the_growthofcanadasorganicsector.html.

8. Зайчук Т. О. (2008). Маркетинговиий підхід до визначення стратегії розвитку сільського господарства України. IX Міжнар. наук.-практ. конф. “Теорія і практика сучасної економіки”: зб. тез доповідей, Черкаси: ЧДТУ, С. 155-158.

9. Дослідження IFC “Інвестиційиий клімат в Україні: яким його бачить бізнес" (2011). Available at: http://www1.ifc.org/wps/wcm/connect/RegProjects_Ext_Content/IFC_External_Corporate_Site/USPP_HomeRU/Proj ectMaterialsRU/. 
State regulation and support of organic farming in Canada and Ukraine: an overview of key indicators...

10. Белінська С. (2011) Концептуальні засади гарантій безпечності харчових продуктів. Проблеми безпечності товарів. Серія: Товари і ринки, №. 1, С. 176.

11. Гончаренко С. Чи безпечний сир в мишоловці? Національний прес-клуб “Українська перспектива”. № 6 (213). Available at: http://malakava.com/articles/12515.

12. Про тенденції розвитку органічного виробництва сільськогосподарської продукції в Україні (2012). (Національний інститут стратегічних досліджень: аналітична записка). Available at: http://www.niss.gov. ua/articles/1292/

13. Сенишин О., Кундицький О. та Клепанчук О. (2019). Індексний аналіз для оцінки конкурентоспроможності харчових продуктів в Україні. Журнал конкурентоспроможності, 11 (2), С. 130-143.

14. Kohls, R. L., \& Uhl, J. N. (1990). Marketing of agricultural products, 7th ed., Macmillan Publishing Company, New York, USA; Collier MacMillan publishers, London, UK.

15. McCall, A., \& Timothy, J. (1997). Agriculture Policies and World Markets. New York, USA; Collier MacMillan publishers, London, UK.

1. Choose Canada organic. Retrieved from: https://choosecanadaorganic.ca/organic101/

2. Artysh V. (2010). Rozvytok svitovoho rynku orhanichnoi produktsii [Development of the world market of organic products]. Ekonomika APK [Economics of the agro-industrial complex], No. 3, pp. 113-116.

3. Zakon Ukrainy vid 03.07.2019 No. 2496-VII "On the basic principles and requirements for organic production, circulation and labeling of organic products" [Law of Ukraine dated 03/07/2019 No. 2496-VII "On the basic principles and requirements for organic production, circulation and labeling of organic products"]. Retrieved from: https://zakon.rada.gov.ua/laws/show/2496-19.

4. Federal-Provincial Agricultural Committee on Environmental Sustainability (1990). Growing Together: Report to Ministry of Agriculture. Ottawa.

5. Zaychuk T. (2009). Vyrobnytstvo ekolohichno chystykh produktiv kharchuvannia yak stratehichnyi napriamok rozvytku Ukrainy [Production of ecologically clean food products as a strategic direction of Ukraine's development]. Ekonomika i rehion. Seriia: Ekonomika ta upravlinnia natsionalnym hospodarstvom [Economy and region. Series: Economics and management of the national economy], No. 1 (20), pp. 101.

6. https://www.fibl.org/fileadmin/documents/shop/5011-organic-world-2020.pdf

7. The official website of Canadian Government. Retrieved from: https://www.canada.ca/en/agriculture-agri food/news/2018/01/supporting_the_growthofcanadasorganicsector.html.

8. Zaychuk T. (2008). Marketynhovyi pidkhid do vyznachennia stratehii rozvytku silskoho hospodarstva Ukrainy [Marketing approach to determining the strategy of agricultural development of Ukraine]. IX International. scientificpractical conf. "Theory and practice of modern economics": coll. abstracts. Cherkasy: ChSTU, pp. 155-158.

9. IFC study "Investment climate in Ukraine: how business sees it" (2011). Retrieved from: http://www1.ifc.org/wps/wcm/connect/RegProjects_Ext_Content/IFC_External_Corporate_Site/USPP_HomeRU/Proj ectMaterialsRU/.

10. Belinska S. (2011). Kontseptualni zasady harantii bezpechnosti kharchovykh produktiv [Conceptual principles of food safety guarantees]. Problemy bezpechnosti tovariv. Seriia: Tovary i rynky [Problems of product safety. Series: Goods and markets], No. 1, pp. 176.

11. Goncharenko S. (2013). Chy bezpechnyi syr v mysholovtsi? [Is cheese safe in a mousetrap?]. Natsionalnyi pres-klub "Ukrainska perspektyva" [National Press-Club "Ukrainian Perspective"], No. 6. Retrieved from: http://malakava.com/articles/12515.

12. On the trends of development of organic production of farming products in Ukraine (2012). (National Institute of strategic studies: analytical note). Retrieved from: http://www.niss.gov.ua/articles/1292.

13. Senyshyn, O., Kundytskyj, O., \& Klepanchuk, O. (2019). An Index Analysis for the Assessment of the Competitiveness of Food Products in Ukraine. Journal of Competitiveness, 11(2), pp. 130-143. Retrieved from: https://doi. org/10.7441/joc.2019.02.09.

14. Kohls, R. L., \& Uhl, J. N. (1990). Marketing of agricultural products, 7th ed., Macmillan Publishing Company, New York, USA; Collier MacMillan publishers, London, UK.

15. McCall, A., \& Timothy, J. (1997). Agriculture Policies and World Markets. New York, USA; Collier MacMillan publishers, London, UK. 


\section{ДЕРЖАВНЕ РЕГУЛЮВАННЯ ТА ПІДТРИМКА \\ ОРГАНІЧНОГО СІЛЬСЬКОГОСПОДАРСЬКОГО ВИРОБНИЦТВА КАНАДИ ТА УКРАЇНИ: ОГЛЯД ОСНОВНИХ ПОКАЗНИКІВ ТА ПОРІВНЯЛЬНИЙ АНАЛІЗ ДВОХ КРАЇН}

\section{С Гвоздь О. М., Горинь М. О., 2020}

Мета органічного сільськогосподарського виробництва - забезпечити людство високоякісною їжею без генетично модифікованих організмів та підтримати концепцію сталого розвитку суспільства. У статті визначено численні переваги органічного сільського господарства, що змушують задуматися про перспективи розвитку світового сільського господарства як одного із ключових факторів, що впливають на майбутнє наступних поколінь. У цій роботі також висвітлено основні передумови необхідності державної підтримки органічного виробництва у світі на прикладі двох великих органічних виробників - Канади та України та виконано порівняльний аналіз сучасного стану розвитку органічного сільськогосподарського виробництва цих країн.

Ключові слова: органічне сільськогосподарське виробництво; органічна продукція; державне регулювання органіки; державна підтримка органічного землеробства; регіональна підтримка органічного землеробства; субсидії на органічне сільське господарство. 